\title{
Water Quality Assessment by Means of Bio-Indication: A Case Study of Ergene River Using Biological Diatom Index
}

\author{
Cem Tokatlı ${ }^{1}$ (D) Cüneyd Nadir Solak ${ }^{2}$ (D), Elif Yılmaz ${ }^{2}$ (D)
}

Cite this article as: Tokatlı, C., Solak, C. N., Yllmaz, E. (2020). Water quality assessment by means of bio-indication: A case study of ergene river using biological diatom index. Aquatic Sciences and Engineering, 35(2), 43-51.

ORCID IDs of the authors: C.T. 0000-0003-2080-7920; C.N.S. 0000-0003-2334-4271; E.Y. 0000-0002-7814-3429

${ }^{1}$ Trakya University, Ipsala Vocational School, Department of Laboratory Technology,

Edirne, Turkey

${ }^{2}$ Dumlupınar University, Faculty of Arts and Sciences, Department of Biology, Kütahya, Turkey

\section{Submitted:}

19.10.2019

Revision Requested: 04.01.2020

Accepted:

11.01.2020

Online published:

10.02.2020

Correspondence:

Cem Tokatlı

E-mail:

tokatlicem@gmail.com

(C) Copyright 2020 by Aquatic

Sciences and Engineering

Available online at

https://dergipark.org.tr/ase

\begin{abstract}
The Ergene River is the most significant fluvial ecosystem located in the Thrace Region of Turkey. But it is being exposed to an intensive organic - inorganic pollution by means of agricultural - industrial applications conducted around its basin. In this research, the epipelic (EPP) diatoms of the Ergene River were investigated and the water quality was evaluated using the determined physical, chemical and biological data. EPP diatom samples were collected from upstream, middlestream and downstream of the Ergene River and certain physicochemical parameters (dissolved oxygen, oxygen saturation, $\mathrm{pH}$, electrical conductivity, total dissolved solids, salinity, turbidity, nitrate, nitrite, ammonium, phosphate, sulphate, fluoride, chemical oxygen demand, biological oxygen demand and oxidation-reduction potential) were measured during the field - laboratory studies. Also, the Biological Diatom Index (BDI) was used to determine the trophic status of the Ergene River in terms of EPP diatoms. According to the results of the physicochemical analysis, upstream of the Ergene River has Class I - II water quality and middle - downstream of the Ergene River have Class III - IV water quality in general. According to the results of the biological analysis, 24 diatom species were recorded in the upstream samples, 4 diatom species were recorded in the middlestream samples. and 7 diatom species were recorded in the downstream samples. Cymbopleura amphicephala (Nägeli) Krammer, Nitzschia umbonata (Ehrenberg) Lange-Bertalot and Nitzschia capitellata Hustedt were determined as the most dominant species in the up - middle - downstream of Ergene River respectively. According to the result of the BDI, the upstream of Ergene River was found to be in an oligotrophic state - has high water quality and the middle - downstream of Ergene River were found to be in a eutrophic state - have poor water quality.
\end{abstract}

Keywords: Ergene River, Bentic diatoms, Biological Diatom Index, Water quality

\section{INTRODUCTION}

Diatoms are algae that are the only organism on the planet with cell walls composed of transparent, opaline silica. Diatom cell walls are also ornamented by intricate and striking patterns of silica. Diatoms have chlorophylls a and c that are light-absorbing molecules. They collect energy from the sun and turn it into chemical energy by means of photosynthesis. Diatoms remove carbon dioxide from the atmosphere and convert it to organic carbon, and release the oxygen. Therefore, they are of vital importance for all organisms living in both aquatic and terrestrial environments. Diatoms are particular about the quality of water. For example, species have distinct ranges of $\mathrm{pH}$ and salinity where they will grow. They also have ranges and tolerances for other environmental factors, including nitrogenous or phosphorus concentration, flow regime, elevation, and organic or inorganic toxicants. Therefore, diatoms are also vital for assessment and monitoring of the envi- 
ronmental condition of water ecosystems (Round et al., 1990; Compton, 2011).

Bioindicator organisms have been widely used in the scientific community for an effective water quality assessment research (Martin et al., 2010; Solak and Acs, 2011; Tokatlı and Dayıoğlu, 2011; Delgado et al., 2012; Atıcı and Udoh, 2016). Diatoms, which are one of the most important aquatic producer groups, can be found in all surface waters all the time. They are accepted as an important part of bioindicator organisms because of having quick reactions to environmental changes. Therefore, diatoms have been used to evaluate environmental conditions in many countries as indicators of water pollution (Ács et al., 2004; Goma et al., 2004; Atıcı and Obalı, 2006; Solak et al., 2007; Kalyoncu et al., 2009; Atıcı and Obalı, 2010; Tokatlı, 2013; Aydın and Büyükışık, 2014; Tan et al., 2017; Tokatlı et al., 2020). Diatom indices are one of the most widely used water quality assessment techniques and the Biological Diatom Index (BDI) is one of the most convenient indexes for evaluating water quality by using diatom communities (Coste et al., 2009).

The Ergene River is the most significant lotic ecosystem for the Thrace Region of Turkey and it is well documented that this system is being exposed to intensive anthropogenic pressure by means of agricultural and industrial applications conducted around the watersheds (Erkmen and Kolankaya, 2006; Tokatlı and Baştatlı, 2016; Tokatlı, 2017). The aim of the present research was to determine the epipelic diatoms of the Ergene River and to evaluate its water quality by using certain physicochemical parameters and the $\mathrm{BDI}$.

\section{MATERIAL AND METHOD}

\section{Study area}

Water samples and epipelic (EPP) diatoms were collected from 3 selected stations on the Ergene River in autumn (rainy season) of 2018. A map of the Ergene River Basin and the selected stations is shown in Figure 1.

\section{Physical and chemical parameters}

The dissolved oxygen, oxygen saturation, $\mathrm{pH}$, electrical conductivity (EC), total dissolved solids (TDS), salinity and ORP parameters were determined using a Hach Lange branded "HQ40D Multiparameter" device during the field studies; the turbidity parameter was determined using a Hach Lange branded "21000 Portable Turbiditymeter" device during the field studies; the nitrate, nitrite, ammonium, phosphate, sulphate, fluorine and COD parameters were determined using a Hach Lange branded "DR3900 Spectrophotometer" device during the laboratory studies; the BOD parameter was determined using a Hach Lange branded "BOD Trak II Biological Oxygen Demand" device during the laboratory studies.

\section{Epipelic (EPP) diatoms}

A glass pipe with a diameter of $0.8 \mathrm{~cm}$ and a length of $100-150$ $\mathrm{cm}$ was used for capturing EPP diatom samples. Then the diatom samples collected from the field were cleaned with acid (98\% $\mathrm{H}_{2} \mathrm{SO}_{4}$ and $35 \% \mathrm{HNO}_{3}$ ) and mounted on a microscope for observation at a magnification of 1000X. Slides were prepared and approximately 400 valves were enumerated on each slide to deter- mine the relation and abundance of each taxa (Sladecova, 1962; Round, 1993). Diatoms were identified according to Cox (1996) and Krammer and Lange-Bertalot (1986; 1988; 1991a; 1991b).

\section{The Biological Diatom Index (BDI)}

The Biological Diatom Index (IBD) values of the up - middle downstreams of the Ergene River were automatically calculated using the "Calculate IBD with Excel" program. The trophic statuses and quality classes of freshwater according to BDI values are given in Table 1 (Lenoir and Coste, 1996).

\begin{tabular}{ccc}
\hline \multicolumn{2}{l}{ Table 1. Scale of BDI } & \\
\hline Index Value & Quality Class & Trophic Status \\
\hline$>17$ & High Quality & Oligotrophic \\
$15-17$ & Good Quality & Oligo - Mesotrophic \\
$12-15$ & Moderate Quality & Mesotrophic \\
$9-12$ & Low Quality & Meso- Eutrophic \\
$<9$ & Poor Quality & Eutrophic
\end{tabular}

\section{RESULTS AND DISCUSSION}

\section{Physical and chemical data}

The results of the physicochemical data detected in the Ergene River and some national - international limit values are given in Table 2. According to the criteria of the Water Pollution Control Regulation in Turkey, upstream of the Ergene River has Class I - II water quality and middle - downstream of the Ergene River have Class III - IV water quality in general (Uslu and Türkman, 1987; Turkish Regulations, 2015).

It is known that the use of organic and inorganic fertilizers, and municipal and industrial wastewater discharges are the most important factors in increasing the amount of nitrogenous and phosphorus in water (Wetzel, 2001; Manahan, 2011). In a study performed in the Meriç, Tunca and Ergene Rivers, water qualities were investigated. As a result of this research and similar to the present study, water quality of the Meriç, Tunca and Ergene Rivers were reported as Class III - IV in terms of nitrite, ammonium and phosphate accumulations (Tokatlı, 2015). In another study performed in the same river basin, the Meriç - Ergene River ecosystem was found to have Class I - II water quality in terms of temperature, DO, COD, $\mathrm{pH}, \mathrm{TDS}$, nitrate, ammonium and sulphate parameters; Class II water quality in terms of nitrite parameters; and Class III - IV water quality in terms of phosphate, BOD and fecal coliform parameters in general (Tokatlı, 2019). According to the DSI observation reports, nitrogen and phosphorus are the main concerns affecting the water quality of Meric - Ergene River Basin (Kendirli et al., 2005). Similar to the data reported by the DSI, the nitrite and phosphate concentrations in the water of middle-downstream of the Ergene River were detected in quite high levels and they have Class III - IV water quality in terms of these parameters.

\section{Biological data}

During the present investigation, a total of 31 diatom species were identified from the epipelic (EPP) habitat of the Ergene River by counting a total of 497 valves in the upstream samples, 67 
valves in the middlestream and 62 valves in the downstream. A list of identified diatom taxa with the frequency values of the investigated stations is given in Table 3. Also, the microscopy pictures of identified diatoms are given in Figure 2 and the relative abundance values of the detected EPP diatoms (higher than 1\%) are given in Figure 3. Cymbopleura amphicephala (Nägeli) Krammer, Nitzschia umbonata (Ehrenberg) Lange-Bertalot and Nitzschia capitellata Hustedt, nom. inval. were determined as the most dominant species in the up - middle - downstream of the Ergene River respectively. Cymbopleura amphicephala, which was recorded as the most dominant taxon (relative abundance of $41 \%$ ) for the upstream samples, is known as a cosmopolitan species found in oligo - mesotrophic waters with a low to moderate electrolyte content. Nitzschia umbonata, which was recorded as the most dominant taxon (relative abundance of 79\%) for the middlestream, is a common species in eutrophic electrolyte rich waters and tolerating extremely polluted conditions. Nitzschia capitellata, which was recorded as the most dominant taxon (relative abundance of $37 \%$ ) for the downstream, is a widespread species occurring in electrolyte rich and brackish waters and tolerating extremely polluted conditions (Taylor et al., 2007).

\section{The biological diatom index (IBD)}

The Biological Diatom Index (BDI), the formula of which was developed by Zelinka and Marvan (1961), is a standardized biological water quality assessment method. It is based on a total of 209 diatom taxa and provides significant information about the tro-
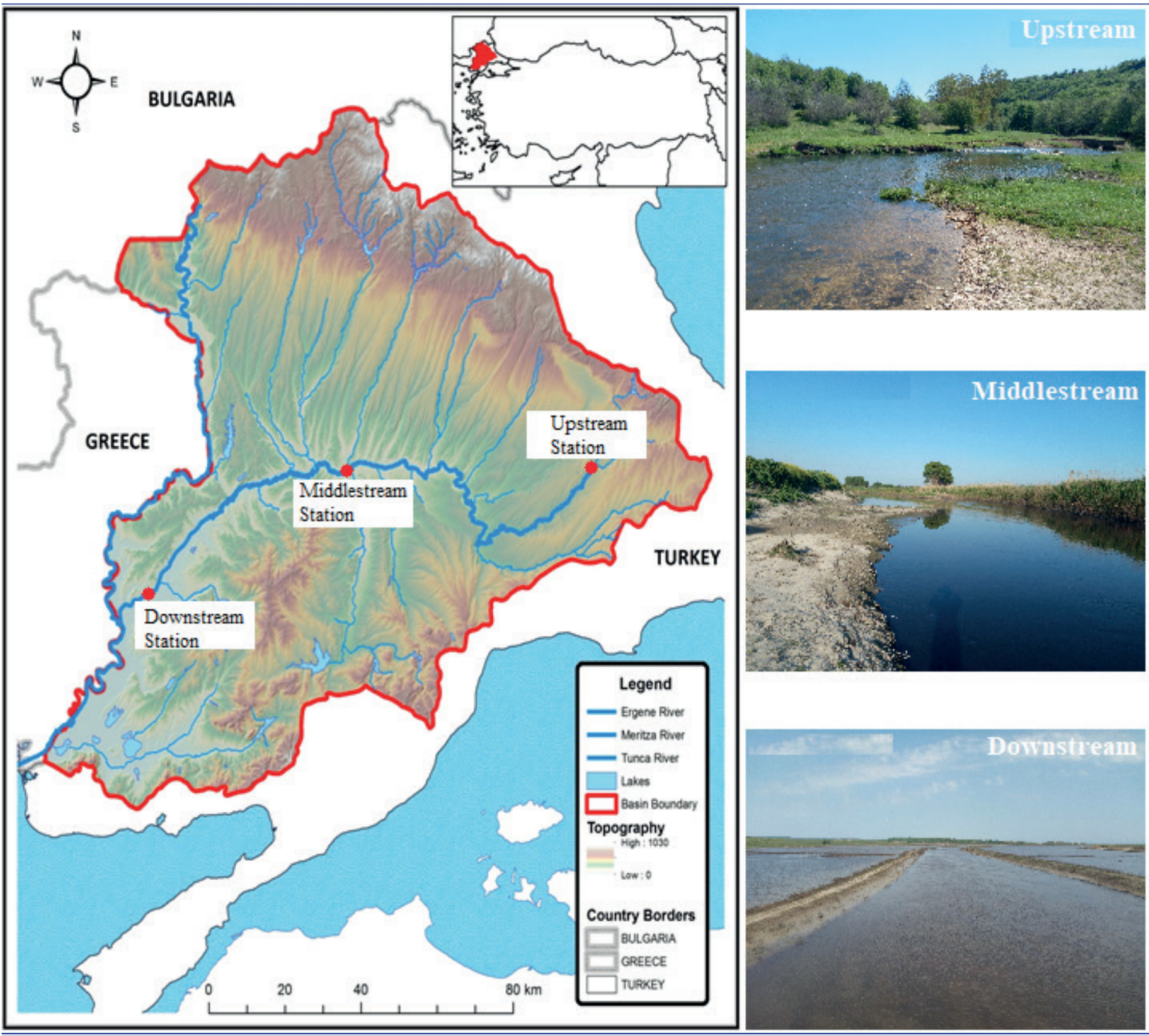

Figure 1. The Ergene River Basin and the selected stations.

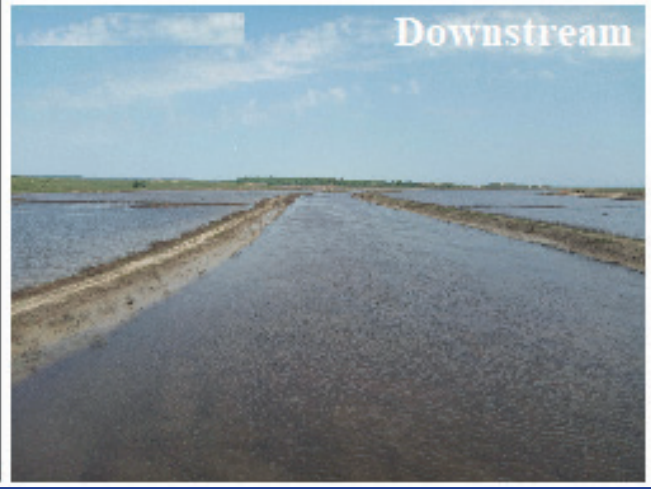




\begin{tabular}{|c|c|c|c|c|c|c|c|}
\hline 屁色 & & & & & & & 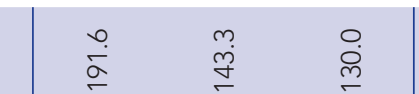 \\
\hline 号高 & $+\infty$ & $\therefore$ & $\stackrel{i}{x}$ & & & & 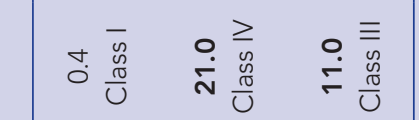 \\
\hline 过高 & $\therefore 8$ & $\therefore$ & i & & & & 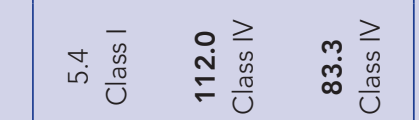 \\
\hline 唔 & $-\stackrel{2}{2}$ & $\sim$ & $\approx$ & $\simeq 2$ & $\stackrel{2}{=}$ & & 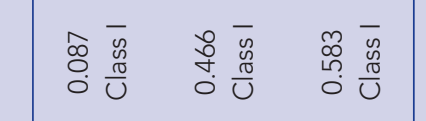 \\
\hline 泀 & $\&$ & \& & 景 & $\stackrel{8}{8}$ & . & & 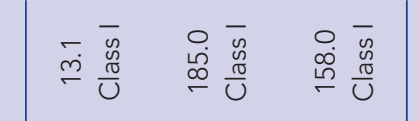 \\
\hline 辛 & 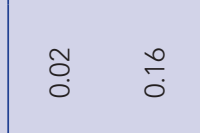 & : & 总 & . & . & & 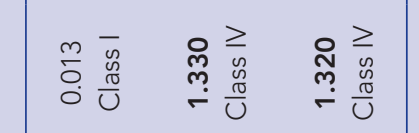 \\
\hline İ & $\approx$ & $\sim$ & 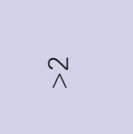 & 용 : & . & $\approx$ 뭉 & 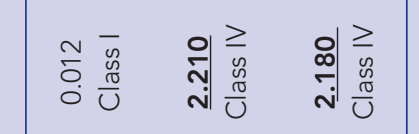 \\
\hline 窟 & รั & 总 & 总 & 옹 몽 & $\approx$ & \%̆ & 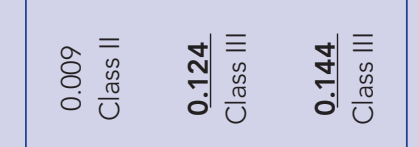 \\
\hline 品商 & $\curvearrowleft \quad$ & $\therefore$ & $\stackrel{i}{i}$ & $\therefore \circ$ & 品 & & 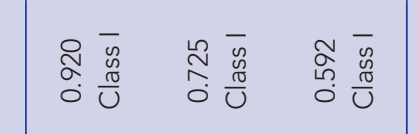 \\
\hline 言空 & ' & . & ' & $\curvearrowleft$ & & & 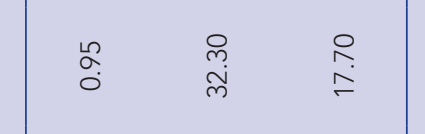 \\
\hline $\bar{\complement} \bar{\circ}$ & & . & . & . & & & $\stackrel{8}{2} \stackrel{8}{-} \stackrel{8}{-}$ \\
\hline 宸离 & 8 & \& & 实 & & & & 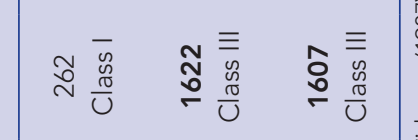 \\
\hline य) & \& & \& & & 兽 & & & 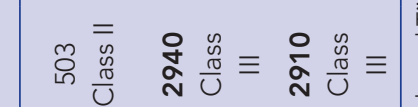 \\
\hline I & 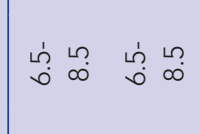 & 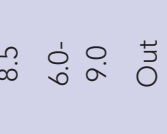 & 5 & 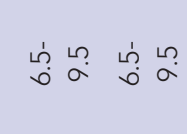 & 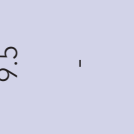 & of & 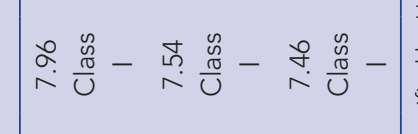 \\
\hline ดั & 28 & q & g & & & & 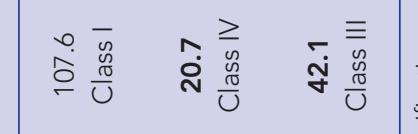 \\
\hline 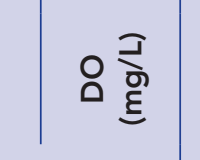 & $\infty \quad 0$ & $\infty$ & v & & & +0 & 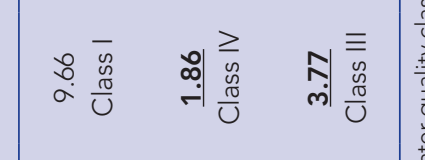 \\
\hline 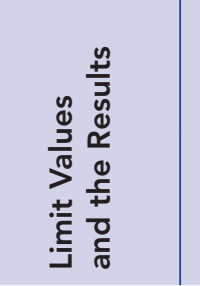 & 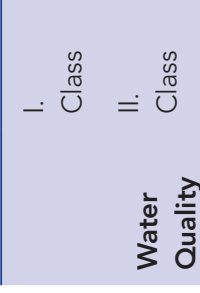 & 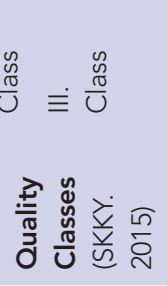 & $\geq \stackrel{\mathscr{2}}{0}$ & 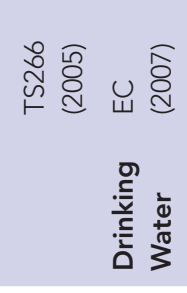 & 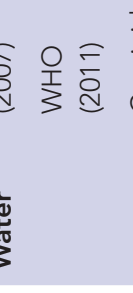 & 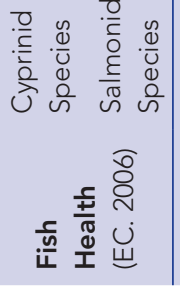 & 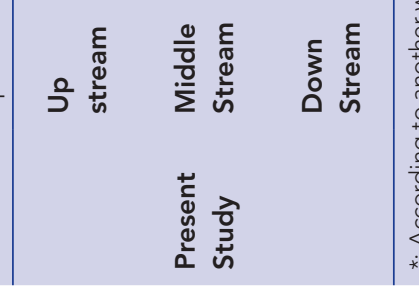 \\
\hline
\end{tabular}




\begin{tabular}{|c|c|c|c|c|}
\hline Species Code & Diatom Taxa & Upstream & Middlestream & Downstream \\
\hline 1 & Amphora pediculus (Kützing) Grunow & + & - & - \\
\hline 2 & Cocconeis pediculus Ehrenberg & + & - & - \\
\hline 3 & Craticula subminuscula (Manguin) C.E.Wetzel \& Ector & - & + & - \\
\hline 4 & Cyclotella meneghiniana Kützing & + & + & - \\
\hline 5 & Cymbella excisa Kützing & + & - & - \\
\hline 6 & Cymbopleura amphicephala (Nägeli) Krammer & + & - & - \\
\hline 7 & Diatoma vulgaris Bory & + & - & - \\
\hline 8 & Diploneis separanda Lange-Bertalot & + & - & - \\
\hline 9 & Encyonema ventricosum (C.Agardh) Grunow & + & - & - \\
\hline 10 & Geissleria decussis (Østrup) Lange-Bertalot \& Metzeltin & + & - & - \\
\hline 11 & Gomphonema italicum Kützing & + & - & - \\
\hline 12 & Grunowia sinuata (Thwaites) Rabenhorst & + & - & - \\
\hline 13 & Melosira varians C.Agardh & + & - & + \\
\hline 14 & Navicula amphiceropsis Lange-Bertalot \& U.Rumrich & - & - & + \\
\hline 15 & Navicula antonii Lange-Bertalot & + & - & - \\
\hline 16 & Navicula capitatoradiata H.Germain ex Gasse & + & - & - \\
\hline 17 & Navicula cryptocephala Kützing & + & - & - \\
\hline 18 & Navicula cryptotenella Lange-Bertalot & + & - & - \\
\hline 19 & Navicula gregaria Donkin & - & - & + \\
\hline 20 & Navicula radiosa Kützing & + & - & - \\
\hline 21 & Navicula reichardtiana Lange-Bertalot & + & - & - \\
\hline 22 & Nitzschia amphibia Grunow & - & - & + \\
\hline 23 & Nitzschia capitellata Hustedt, nom. inval. & - & + & + \\
\hline 24 & Nitzschia dissipata (Kützing) Rabenhorst & + & - & - \\
\hline 25 & Nitzschia linearis W.Smith & + & - & - \\
\hline 26 & Nitzschia sublinearis Hustedt & + & - & - \\
\hline 27 & Nitzschia subtilis (Kützing) Grunow & + & - & - \\
\hline 28 & Nitzschia umbonata (Ehrenberg) Lange-Bertalot & - & + & + \\
\hline 29 & Tryblionella hungarica (Grunow) Frenguelli & - & - & + \\
\hline 30 & Ulnaria acus (Kützing) Aboal & + & - & - \\
\hline 31 & Ulnaria ulna (Nitzsch) Compère & + & - & - \\
\hline
\end{tabular}

phic levels of the investigated aquatic habitat (Coste et al., 2009). In this research, a total of 31 diatom taxa were identified and they were used to calculate the Biological Diatom Index (BDI) scores of the up - middle - downstreams of the Ergene River in order to determine the trophic status. The BDI values of the investigated locations are given in Figure 4. According to the calculated BDI values for the EPP habitats, upstream of the Ergene River was found to be in an oligotrophic state - has high water quality (score range of $>17$ ) and middle - downstream of the Ergene River were found to be in a eutrophic state - have poor water quality (score range of <9).

The physical and chemical parameters used to assess water quality may only indicate the current status of the investigated aquatic ecosystem. However, the bioindicator organisms like diatoms may indicate the long-term changes in water ecosystems. Therefore, they have been widely used for the bio-assessment of aquatic habitats in almost all the countries of Europe due to their broad distribution and their quick reaction to environmental changes in water (Acs et al., 2004; Torissi and Dell'Uomo, 2006; Solak and Acs, 2011). Many diatom indices have been developed and they are widely used to determine the quality and trophic levels of water ecosystems. In a study performed in Poland, the Biological Diatom
Index (BDI) was used for the assessment of water quality in the Pilica River. As a result of this study, the ecological state of the Pilica River changed from good (oligo - mesotrophic) to moderate (mesotrophic) (Szulc and Szulc, 2013). In another research performed in Vietnam, the BDI was used to evaluate the water quality of the Dong Nai River. As a result of this study, the water quality of the investigated river varied from good (oligo-mesotrophic), moderate (mesotrophic), to low (meso - eutrophic) levels (Pham, 2017). Several studies have also been carried out in different aquatic habitats of Turkey. Gürbüz and Kıvrak (2002) applied Saprobity Index (SI) and Trophic Diatom Index (TDI) in order to assess the water quality of Karasu River. According to the results of this investigation, the Karasu River was found to be in a eutrophicated state and organically polluted. Kalyoncu et al. (2009) investigated the Darı̈ren Stream by ecological methodologies to evaluate the impact of pollution on epilithic diatom assemblages. Solak (2011) also used the SLA, EPI-D, TDI and DESCY indices to evaluate the water quality of the Upper Porsuk River (Kütahya). In two studies performed in the Gürleyik and Seydisuyu Streams, the BDI was used to assess the water qualities and the results of these studies showed that in line with the investigated physicochemical data, the Gürleyik and Seydisuyu Streams were found to be in a mesotrophic state (TokatIı, 2012, Atıcı et al., 2018). 


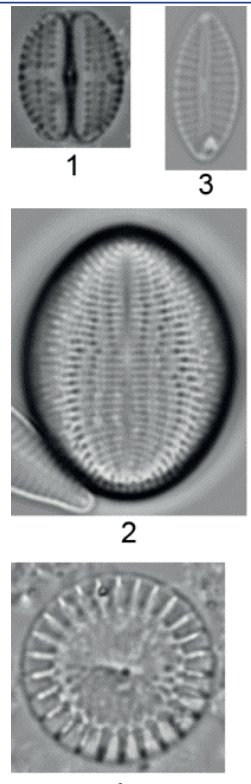

4

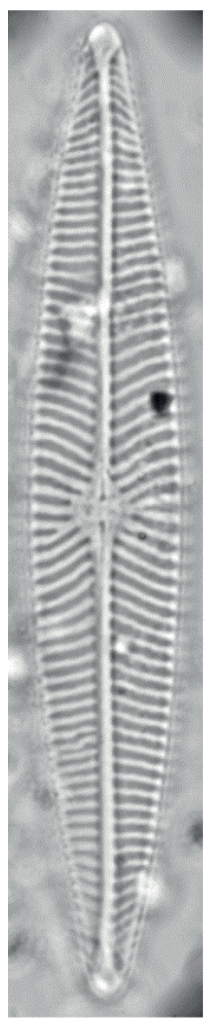

20

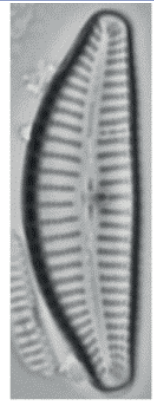

5

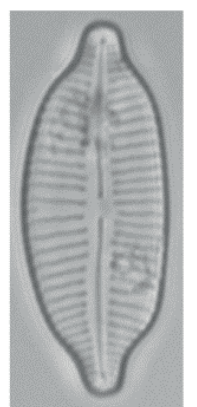

6
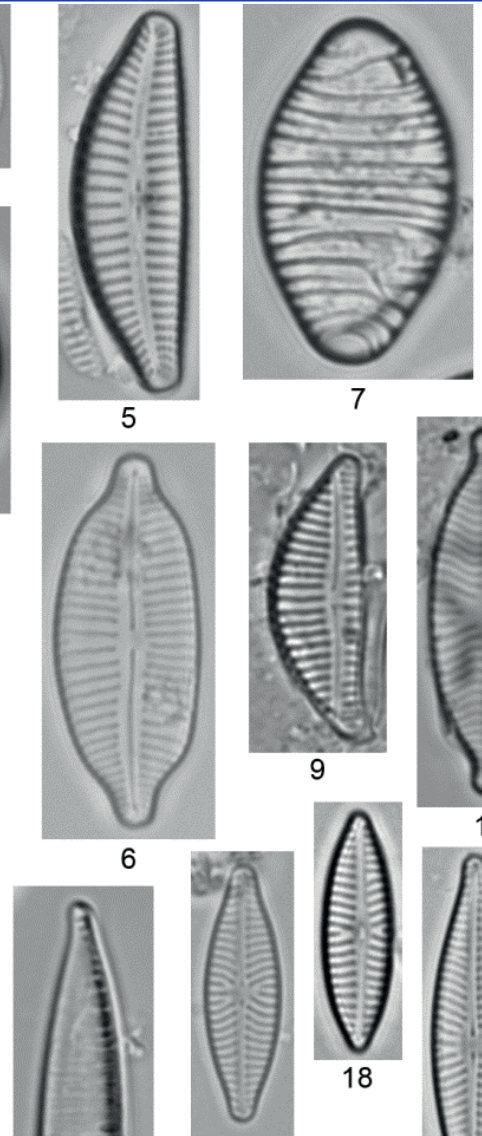

7

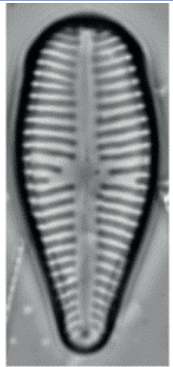

11

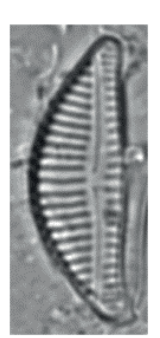

9
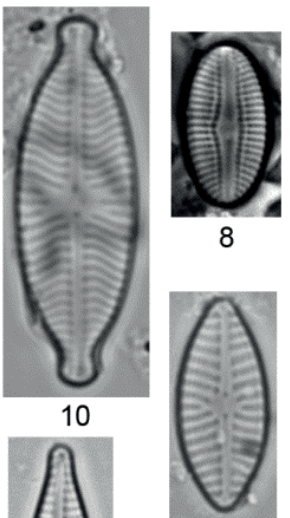

15

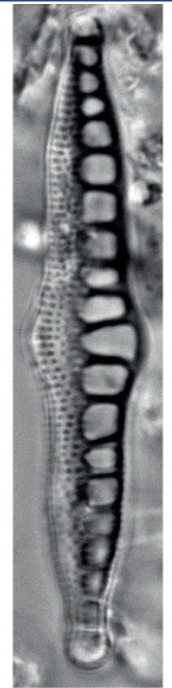

12

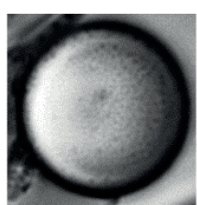

13
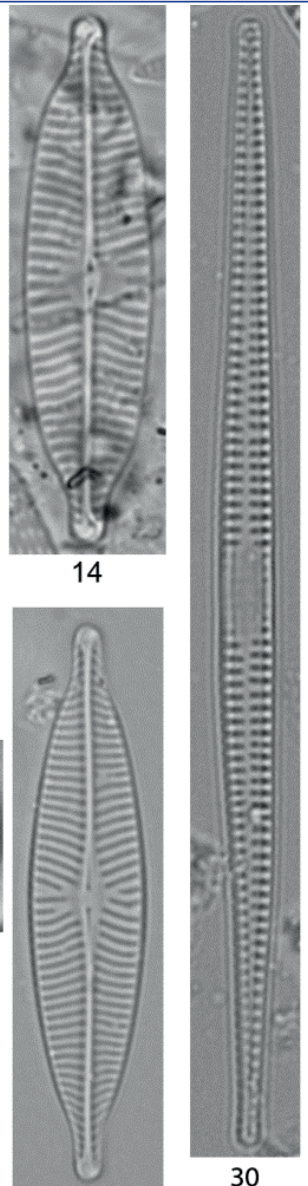

16

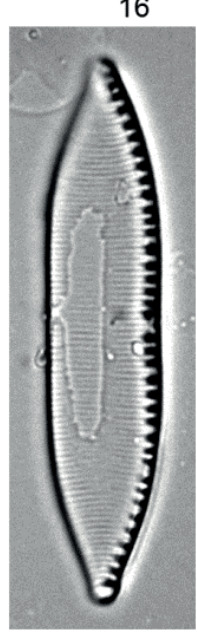

28

Figure 2. Microscopy pictures of Ergene River diatoms

In the present investigation, the BDI was used to assess the water quality of the Ergene River and the detected data was compared with the results of limnological data. Similar to the resulting limnological data, upstream of the Ergene River was found to be in an oligotrophic state and has high water quality according to the result of the BDI and has Class I - II water quality according to the results of physicochemical parameters. Middle-down- stream of the Ergene River were found to be in a eutrophic state and have poor water quality according to the result of the BDI and have Class III - IV water quality according to the results of physicochemical parameters. The detected similarities in water quality status between the results of the BDI scores and the psychochemical parameters indicate that the BDI may be used to reflect changes in ecological conditions of the Ergene River. 


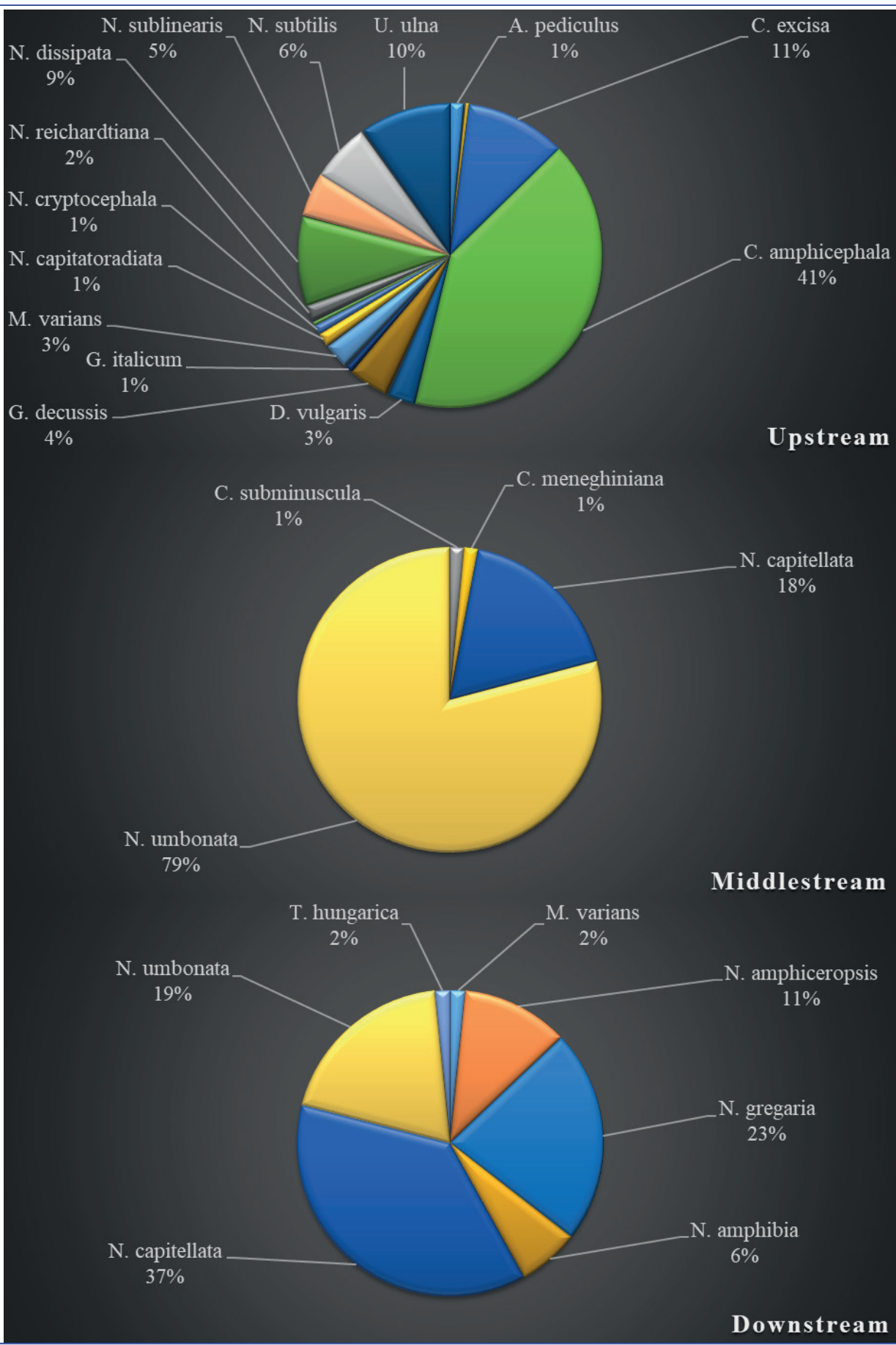

Figure 3. Relative abundance of diatoms in the Ergene River.

\section{CONCLUSION}

It is clearly known that biological water quality assessment is much more effective than investigated physicochemical data in terms of reflecting any environmental effects on aquatic ecosystems. Therefore, in order to make a better aquatic ecosystem quality assessment research, physicochemical data should be supported by biological data. In the present study, the epipelic diatoms of the Ergene River were investigated and the water quality of this significant river was evaluated using the Biological Diatom Index (BDI).

As a result of this research, 24 diatom species were recorded in the upstream samples, 4 diatom species were recorded in the middlestream samples and 7 diatom species were recorded in the downstream samples. Cymbopleura amphicephala which has a narrow ecological valence and low tolerance, Nitzschia umbonata and Nitzschia capitellata which have a wide ecological 


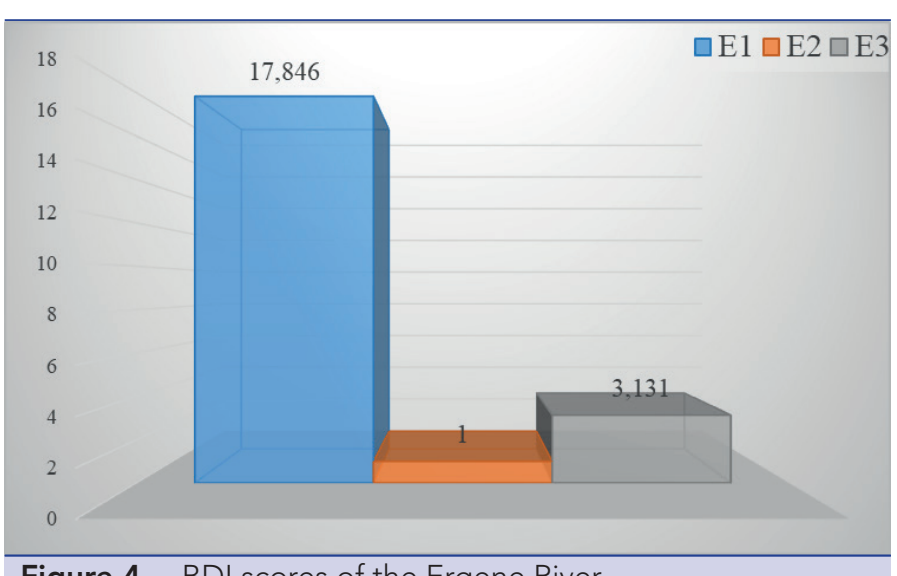

Figure 4. $\mathrm{BDI}$ scores of the Ergene River.

valence and high tolerance were determined as the most dominant species in the up - middle - downstreams of the Ergene River respectively. It was also determined that upstream of the Ergene River was found to be in a Class I - II water quality status and middle - downstream of the Ergene River were found to be in a Class III - IV water quality statuses according to the results of limnological parameters. And, similar to the abiotic data, upstream of the Ergeen River was found to be in an oligotrophic state and has high water quality and middle -downstreams of the Ergene River were found to be in a eutrophic state and have poor water quality according to the results of $\mathrm{BDI}$.

The results of this study also revealed the benefits of using biotic and abiotic factors together in water quality assessment studies and showed that minor changes in environmental conditions may cause major effects in the diatom communities. While the sampling frequency is perhaps not sufficient and more research is needed for the assessment of quality status of the investigated water ecosystem, the results of the present research do have the characteristics of a preliminary research with the aim of providing resources for any future bioindication investigation in the region.

Financial Disclosure: The present study was funded by the Commission of Scientific Research Projects at Trakya University (Project No. 2018/154).

Ethics committee approval: Ethics committee approval is not required.

Conflict of Interest: The authors have no conflicts of interest to declare.

\section{REFERENCES}

Ács, É., Szabó, K., Tóth, B. \& Kiss, K. T. (2004). Investıgatıon of benthıc algal communitıes, especially diatoms of some Hungarian streams in connection with reference conditions of the water framework directives. Acta Botanica Hungarica, 46(3-4), 255-277. [CrossRef]

Atici, T. \& Obali, O. (2006). Seasonal Variation of Phytoplankton and Value of Chlorophyll a in the Sariyar Dam Reservoir (Ankara, Turkey). Turkish Journal of Botany, 30, 349-357.

Atici, T. \& Obali, O. (2010). The diatoms of Asartepe Dam Lake (Ankara), with environmental and some physicochemical properties. Turkish Journal of Botany, 34, 541-548.
Atıcı, T., Tokatlı, C. \& Çiçek, A. (2018). Diatoms of Seydisuyu Stream Basin (Turkey) and Assessment of Water Quality by Statistical and Biological Approaches. Sigma Journal of Engineering and Natural Sciences, 36(1), 271-288.

Atici, T. \& Udoh, A. (2016). Indicator Algae of Adrasan Stream (Antalya) Turkey. Sinop Üniversitesi Fen Bilimleri Dergisi, 1, 140-154.

Aydın, G. Ş. \& Büyükışık, B. (2014). Effects on The Species Specific Variables Nutrient Pulses: Thalassiosira allenii (Takano). Journal of Tekirdag Agricultural Faculty, 11(3), 82-90.

Compton, J. C. (2011). Diatoms: Ecology \& Life Cycle. Nova Science Publishers, $329 \mathrm{pp}$.

Coste, M., Boutry, S., Tison-Rosebery, J. \& Delmas, F. (2009). Improvements of the Biological Diatom Index (BDI): Description and efficiency of the new version (BDI-2006). Ecological Indicators, 9, 621-650. [CrossRef]

Cox, E. J. (1996). Identification of Freswater Diatoms from Live Material. Chapman \& Hall, First Edition, 158 pp.

Delgado, C., Pardo, I. \& García, L. (2012). Diatom communities as indicators of ecological status in Mediterranean temporary streams (Balearic Islands, Spain). Ecological Indicators, 15, 131-139. [CrossRef]

EC (European Communities) (2006). EC of the European Parliament and of the council of 6 September 2006 on the quality of fresh waters needing protection or improvement in order to support fish life. Directive 2006/44.

EC (European Communities) (2007). European Communities (drinking water) (no. 2), Regulatıons 2007, S.I. No. 278 of 2007.

Erkmen, B. \& Kolankaya, D. (2006). Determination of organochlorine pesticide residues in water, sediment, and fish samples from the Meriç Delta, Turkey. International Journal of Environmental Analytical Chemistry, 86(1-2), 161-169. [CrossRef]

Gomà, J., Ortiz, R., Cambra, J. \& Ector, L. (2004). Water quality evaluation in Catalonian Mediterranean Rivers using epilithic diatoms as bioindicators. Vie Milieu, 54, 81-90.

Gürbüz, H., Kivrak, E. (2002). Use of epilithic diatoms to evaluate water quality in the Karasu River of Turkey. Journal of Environmental Biology, 23(3), 239-246.

Kalyoncu, H., Çiçek, N. L., Akköz, C. \& Yorulmaz, B. (2009). Comparative performance of diatom indices in aquatic pollution assessment. African Journal of Agricultural Research, 4(10), 1032-1040.

Kendirli, B., Çakmak, B. \& Gökalp, Z. (2005). Assessment of Water Quality Management in Turkey. Water International, 30(4), 446-455. [CrossRef]

Krammer, K. \& Lange-Bertalot, H. (1986). Bacillariophyceae. 1. Teil: Naviculaceae. Süßwasser von mitteleuropa, Gustav Fischer Verlag, Band 2-1, Stuttgart.

Krammer, K. \& Lange-Bertalot, H. (1988). Bacillariophyceae. 2. Teil: Bacillariophyceae, Epithemiaceae, Surirellaceae. Süßwasser von mitteleuropa, Gustav Fischer Verlag, Band 2-2, Stuttgart.

Krammer, K. \& Lange-Bertalot, H. (1991a). Bacillariophyceae. 3. Teil: Centrales, Fragilariaceae, Eunotiaceae. Süßwasser von mitteleuropa, Gustav Fischer Verlag, Band 2-3, Stuttgart.

Krammer, K. \& Lange-Bertalot, H. (1991b). Bacillariophyceae. 4. Teil: Achnantheceae, Kritische Ergänzungen zu Navicula (Lincolatae) und Gomphonema, Cesamptliteraturverzeichnis. Süßwasser von mitteleuropa. Gustav Fischer Verlag, Band 2-4, Stuttgart.

Lenoir, A. \& Coste, M. (1996). Development of a practical diatom index of overall water quality applicable to the French national water board network. In: B. A. Whitton and E. Rott (Eds.), Use of Algae for Monitoring Rivers, II. Institut fur Botanik. Univ. Innsbruck 29-43.

Manahan, S. E. (2011). Water Chemistry: Green Science and Technology of Nature's Most Renewable Resource. Taylor \& Francis Group, CRC Press, 398 pages. [CrossRef] 
Martín, G., Toja, J., Sala, S. E., Fernández, M. R., Reyes, I. \& Casco, M. A. (2010). Application of diatom biotic indices in the Guadalquivir River Basin, a Mediterranean basin. Which one is the most appropriated? Environmental Monitoring and Assessment, 170, 519-534. [CrossRef]

Pham, T.L. (2017). Comparison between Water Quality Index (WOI) and biological indices, based on planktonic diatom for water quality assessment in the Dong Nai River, Vietnam. Pollution, 3(2), 311-323.

Round, F. E. (1993). A Reviev and Methods for The Use of Epilithic Diatoms for Detecting and Monitorin Changes in River Water Quality. HMSO, London.

Round, F. E., Crawford, R. M., Mann, D. G. (1990). The Diatoms: Biology and Morphology of the Genera. Cambridge University Press, 751 pp.

Sladeckova, A. (1962). Limnological investigation methods for periphyton (Aufwusch) community. Botanical Review, 28, 286-350. [CrossRef]

Solak, C. N. (2011). The application of diatom indices in the Upper Porsuk River, Kütahya - Turkey. Turkish Journal of Fisheries and Aquatic Sciences, 11(1), 31-36. [CrossRef]

Solak, C. N., Fehér, G., Barlas, M. \& Pabuçcu, K. (2007). Use of epilithic diatoms to evaluate water quality of Akçay Stream (Büyük Menderes River) in Mugla/Turkey. Large Rivers, 17, 327-338. [CrossRef]

Solak, C. N. \& Acs, E. (2011). Water Quality Monitoring in European and Turkish Rivers Using Diatoms. Turkish Journal of Fisheries and Aquatic Sciences, 11, 329-337. [CrossRef]

Szulc, B. \& Szulc, K. (2013). The use of the Biological Diatom Index (BDI) for the assessment of water quality in the Pilica River, Poland. Oceanological and Hydrobiological Studies, 42(2), 188-194. [CrossRef]

Tan, X., Zhang, Q., Burford, M. A., Sheldon, F. \& Bunn, S. E. (2017). Benthic Diatom Based Indices for Water Quality Assessment in Two Subtropical Streams. Frontiers in Microbiology, 8, 601. [CrossRef]

Taylor, J. C., Harding, W. R. \& Archibald, C. G. M. (2007). An illustrated guide to some common diatom species from South Africa. Report to the water research commission.

Tokatlı, C. (2012). Sucul Sistemlerin İzlenmesinde Bazı Diyatome Indekslerinin Kullanılması: Gürleyik Çayı Örneği (Eskişehir). Dumlupınar Üniversitesi Fen Bilimleri Enstitüsü Dergisi, 29, 19-26.

Tokatlı, C. (2013). Evaluation of Water Quality by Using Trophic Diatom Index: Example of Porsuk Dam Lake. Journal of Applied Biological Sciences, 7, 1-4.

Tokatlı, C. (2015). Assessment of the Water Quality in the Meriç River: As an Element of the Ecosystem in the Thrace Region of Turkey. Polish Journal of Environmental Studies, 24(5), 2205-2211. [CrossRef]
Tokatlı, C. (2017). Bio - Ecological and Statistical Risk Assessment of Toxic Metals in Sediments of a Worldwide Important Wetland: Gala Lake National Park (Turkey). Archives of Environmental Protection, 43(1), 34-47. [CrossRef]

Tokatlı, C. (2019). Water and Sediment Quality Assessment of the Lifeblood of Thrace Region (Turkey): Meriç River Basin. Fresenius Environmental Bulletin, 28(5), 4131-4140.

Tokatlı, C. \& Baștatlı, Y. (2016). Trace and Toxic Element Levels in River Sediments. Polish Journal of Environmental Studies 25(4), 1715-1720. [CrossRef]

Tokatlı, C. \& Dayıoğlu, H. (2011). Use of Epilithic Diatoms to Evaluate Water Quality of Murat Stream (Sakarya River Basin, Kütahya): Different Saprobity Levels and $\mathrm{pH}$ Status. Journal of Applied Biological Sciences, 5(2), 55-60.

Tokatlı, C., Köse, E. \& Çiçek, A. (2014). Assessment of the Effects of Large Borate Deposits on Surface Water Quality by Multi Statistical Approaches: A Case Study of the Seydisuyu Stream (Turkey). Polish Journal of Environmental Studies, 23(5), 1741-1751.

Tokatlı, C., Solak, C. N., Yılmaz, E., Atıcı, T., Dayıoğlu, H. (2020). A Research on Epipelic Diatoms of Meriç and Tunca Rivers and Application of Biological Diatom Index for Water Quality Assessment. Aquatic Sciences and Engineering, 35(1), 19-26. [CrossRef]

Torrisi, M. \& Dell'uomo, A. (2006). Biological monitoring of some Apennine rivers (Central Italy) using the diatom-based Eutrophication/ Pollution Index (EPI-D) compared to other European diatom indices. Diatom Research, 21, 159-174. [CrossRef]

TS 266 (2005). Sular-İnsani tüketim amaçlı sular. Türk Standartları Enstitüsü, ICS 13.060.20.

Turkish Regulations, 2015. Yüzeysel Su Kalitesi Yönetimi Yönetmeliği, 15 Nisan 2015 tarihli Resmi Gazete, Sayı: 29327.

Uslu, O. \& Türkman, A. (1987). Su Kirliliği ve Kontrolü. T.C. Başbakanlık Çevre Genel Müdürlüğü Yayınları, Eğitim Dizisi I, Ankara.

Wetzel, R. G. (2001). Limnology: Lake and River Ecosystems. Elsevier Academic Press, 1006 pages.

WHO (World Health Organization) (2011). Guidelines for Drinking-water Quality. World Health Organization Library Cataloguing-inPublication Data, NLM classification: WA 675.

Zelinka, M. \& Marvan, P. (1961). Zur Präzisierung der biologischen klassifikation der Reinheit fließender Gewässer. Archiv fu $\beta r$ Hydrobiologie, 57, 389-407. 